\title{
DETERMINATION OF RELATIONSHIP BETWEEN WATER LEVEL, VOLUME AND METEOROLOGICAL VARIABLES: STUDY OF LAKE EGIRDIR
}

\author{
Atilgan Atilgan', Ali Yuecel ${ }^{2}$, Monika Markovic ${ }^{3}$ \\ ${ }^{1}$ Isparta University of , Turkey; ${ }^{2}$ Osmaniye Korkut Ata University, Turkey; \\ ${ }^{3}$ Josip Juraj Strossmayer University of Osijek, Croatia \\ atilganatilgan@isparta.edu.tr, aliyuce1965@gmail.com, monika.markovic@ fazos.hr
}

\begin{abstract}
Climate change and variability, as well as unplanned and irregular water use, affect sustainable management of lakes, which are of great importance in terms of water resources. Currently, Lake Egirdir, which is the second largest freshwater resource of our country and located in the Lakes Region, has been selected as the research area. In this study, data of Lake Egirdir water level measurement station and Egirdir meteorology station, which are effective on water potential of Lake Egirdir basin, were used as materials. In this study, Lake Egirdirwater level (EWL) and lake water volume (EWV) values and long-term temperature, rainfall, relative humidity, wind speed values of Lake Egirdir were used. Correlation and regression analyzes were performed to determine the relationships between EWL and EWV values and meteorological variables. Statistical compliance was examined by correlation (r) and probability (p) tests at $5 \%$ significance level. In conclusion, while there are general changes in EWL and EWV values, it has been determined that there are generally decreases since 2004. When the long-year changes are generally examined, it was determined that there was an average decrease of $0.833 \mathrm{~m}(0.091 \%)$ in EWL values and $698.956 \mathrm{hm}^{3}(18.750 \%)$ in EWV values. In addition, the increase in maximum temperature, maximum relative humidity and maximum wind speed in the lake basin, while the decrease in total annual precipitation affected EWL and EWV changes. It has been concluded that as a result of agricultural activities, water use for irrigation purposes and drinking water supply for settlements affect EWL and EWV in Lake Egirdir basin. In addition, it is inevitable that the lack of planning for the use of water resources will adversely affect our water resources with climate change.
\end{abstract}

Keywords: Lake Egirdir, temperature, precipitation, water level, water volume.

\section{Introduction}

Climatic data elements and their characteristics have been affected significantly due to the changes in climate resulting with the increase of greenhouse gases. Climatic data elements can be determined by assessing the long-term averages (LTA) of meteorological data. Even though the averages of climatic data elements characterize the local or regional climate type, they may not fully represent all climate events [1]. Thus, short term maximum and minimum events should also be taken into consideration in addition to the averages of daily climatic data elements. As meteorological events may have significant impacts, that should not be neglected at critical times, even though the lives of living beings mostly depending on averages [2-4]. Moreover, it is also important to examine the changes on open water surfaces in addition to the changes in climatic data elements in order to determine the local or regional impacts of climate change [5-7]. Lakes, as the most important sources of fresh water in the world, are affected by negative impacts of surface flows, underground waters, tectonic activities and anthropogenic adversities [8]. The impact of climate change on water resources is especially affected by the change in rainfall characteristics. Rainfall is indicated as the primary source of the variation in water balance at the scale of space and time. The changes in ecosystem that have occurred as a result of climate change may have important outcomes for hydrology and water sources [6;9].

The previously published results [10] on Lake Egirdir have demonstrated that the lowest water level of the lake was $915.33 \mathrm{~m}$, the lake area was 45300 ha and the water volume was 2.74 billion $\mathrm{m}^{3}$. It was reported that the highest water level of the lake was $919.11 \mathrm{~m}$, the lake area was 48150 ha and the water volume was 4.44 billion $\mathrm{m}^{3}$. Lakes are affected by global climate change, because they form an important geographical ecosystem for the environment and are very sensitive to meteorological conditions [11]. The water level of the lakes is a structure formed in the complex circulation of natural water between the catchment basins. Therefore, long-term fluctuations in the lake water level reflect the climate changes occurring in the region [12]. Wu (2019) [13], in his study, examined the effects of climatic variables on the water levels of 329 lakes by various statistical methods. He determined that the relationship between the lake water levels and precipitation is important. He also stated that there was a decrease in lake water levels with the increase of temperatures. 
The sustainability of water sources have started to gain more importance especially due to the climate change and variability that was developed due to the irrational use of natural resources that started during the mid-1990s. For this purpose, Lake Egirdir, which is the second largest fresh water source in the Republic of Turkey, was selected as the study area. Correlation and regression analyses were carried out for determining the impacts of the meteorological variables (long term temperature, precipitation, relative humidity, wind speed) on the lake water level and lake water volume during 1988-2018 period.

\section{Materials and methods}

Lake Egirdir is located within the borders of Isparta province in the Lakes region, between the

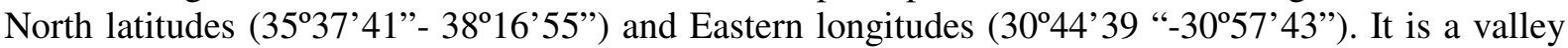
lake formed geologically in tectonic and karstic form. The lake is about $917.7 \mathrm{~m}$ a.s.l., the surface area is $488 \mathrm{~km}^{2}$, the basin area is $3309 \mathrm{~km}^{2}$ and its approximate active volume is $1905 \mathrm{hm}^{3}[1 ; 10 ; 14-17]$.

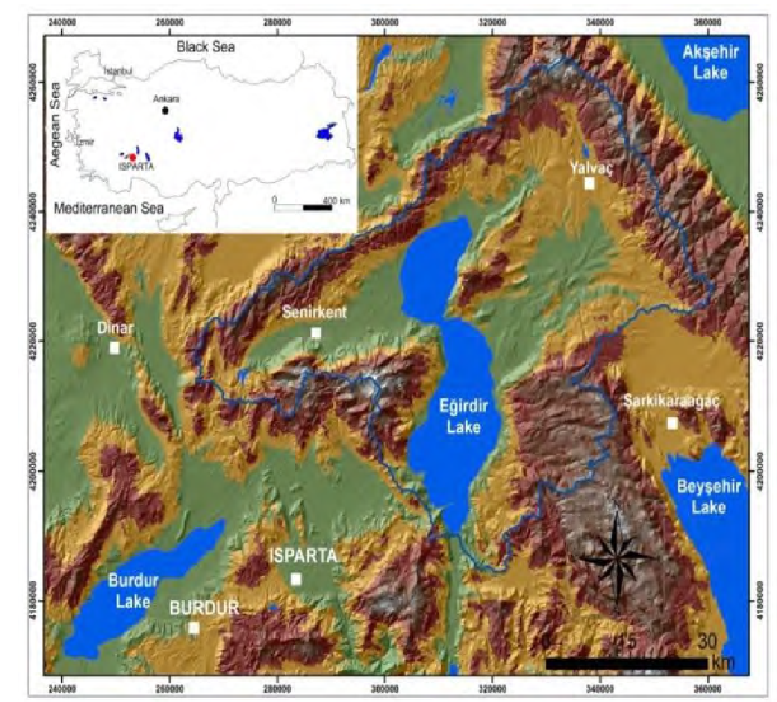

Fig. 1. Location and boundaries of the study area [18]

In the study, Eğirdir lake located in the Lakes Region was chosen as the research area. The studied period is from 1988 to 2018, Egirdir lake water level (EWL) and water volume (EWV) measurement station [19] and Egirdir district meteorology station meteorological values (long term temperature, precipitation, relative humidity, wind speed) were used [20]. Correlation and regression analyses were conducted to determine the relationship between EWL, EWV and meteorological variables. Correlation analysis is a statistical method used to determine the degree and direction of the relationship between two variables. The $r$ coefficient can be calculated using the following equation (1):

$$
r=\frac{\sum_{i=1}^{n}\left(x_{i}-\bar{x}\right)\left(y_{i}-\bar{y}\right)}{\sqrt{\sum_{i=1}^{n}\left(x_{i}-\bar{x}\right)^{2} \sum_{i=1}^{n}\left(y_{i}-\bar{y}\right)^{2}}}
$$

where $x_{i}$-independent variable;

$y_{i}-$ dependent variable;

$\bar{x}$ - mean of the independent variable;

$\bar{y}$ - mean of the dependent variable;

$n-$ total number of observations [21-25].

Probability value $(p)$ : It is a value used for the purpose of determining the presence of statistical difference in studies, if any, the level of this difference (statistical comparison). The $p$ value is made to check the probability of making incorrect decisions, when there is a statistically significant difference in differences [26-28]. 


\section{Results and discussion}

The temperatures for Lake Egirdir (1988-2018) along with the EWL and EWV values are presented in Figure 2. Long term EWL values were determined as; $917.095 \pm 0.537 \mathrm{~m}$ on average, maximum $918.051 \mathrm{~m} \mathrm{(2004)}$ and minimum $916.028 \mathrm{~m}$ (1995). Whereas long term EWV values were determined as; $3377.488 \pm 231.333 \mathrm{hm}^{3}$ on average, maximum $3774.435 \mathrm{hm}^{3}$ (2000) and minimum $2998.937 \mathrm{hm}^{3}$ (2009). It was determined, when long term changes were examined, that there is an average decrease of $0.833 \mathrm{~m}(0.091 \%)$ in EWL values and a decrease of $698.956 \mathrm{hm}^{3}(18.750 \%)$ in EWV values. While it can be observed, when the changes in EWL values are considered, that the value of $918.5 \mathrm{~m}$ in 2004 could not be attained in the coming years and that EWL was always under this level afterwards. It was also observed that the EWV value of $3774.435 \mathrm{hm}^{3}$ in 2000 could not be attained again in later years (Figure 2). It was noticed, when the long term temperature values were $T_{\max }$ is $38.6{ }^{\circ} \mathrm{C}, T_{\text {avg }}$ is $12.36{ }^{\circ} \mathrm{C}$ and $T_{\min }$ is $-14.9^{\circ} \mathrm{C}$. Furthermore, it was noticed, when the changes in $T_{\max }, T_{\text {avg }}$ and $T_{\min }$ temperature values were examined, that there is an increase of $0.50{ }^{\circ} \mathrm{C}(13.731 \%)$ in $T_{\max }$ along with an increase of $1.84^{\circ} \mathrm{C}(13.38 \%)$ in $T_{\text {avg }}$ and an increase of $3.40{ }^{\circ} \mathrm{C}(37.0 \%)$ in $T_{\min }$. Motiee and Makbin [29] found that the climate change causes to reduce $50 \mathrm{~cm}$ water level of the Superior Lake located in North America and that in a short period of time the water level of the lake has been decreased by $1 \mathrm{~cm} \cdot$ year $^{-1}$. According to Tan et al. [11], the relationship between lakes and climate change is complicated. The author claims that the water levels of global lakes show a rising trend and are closely related to the increases in temperature and precipitation. Precipitation mainly affects lakes that are primarily supplied by precipitation and surface runoff. Furthermore, the author has stated that the effect of temperature on the lake water level is through melting of ice and snow and evaporation rate.
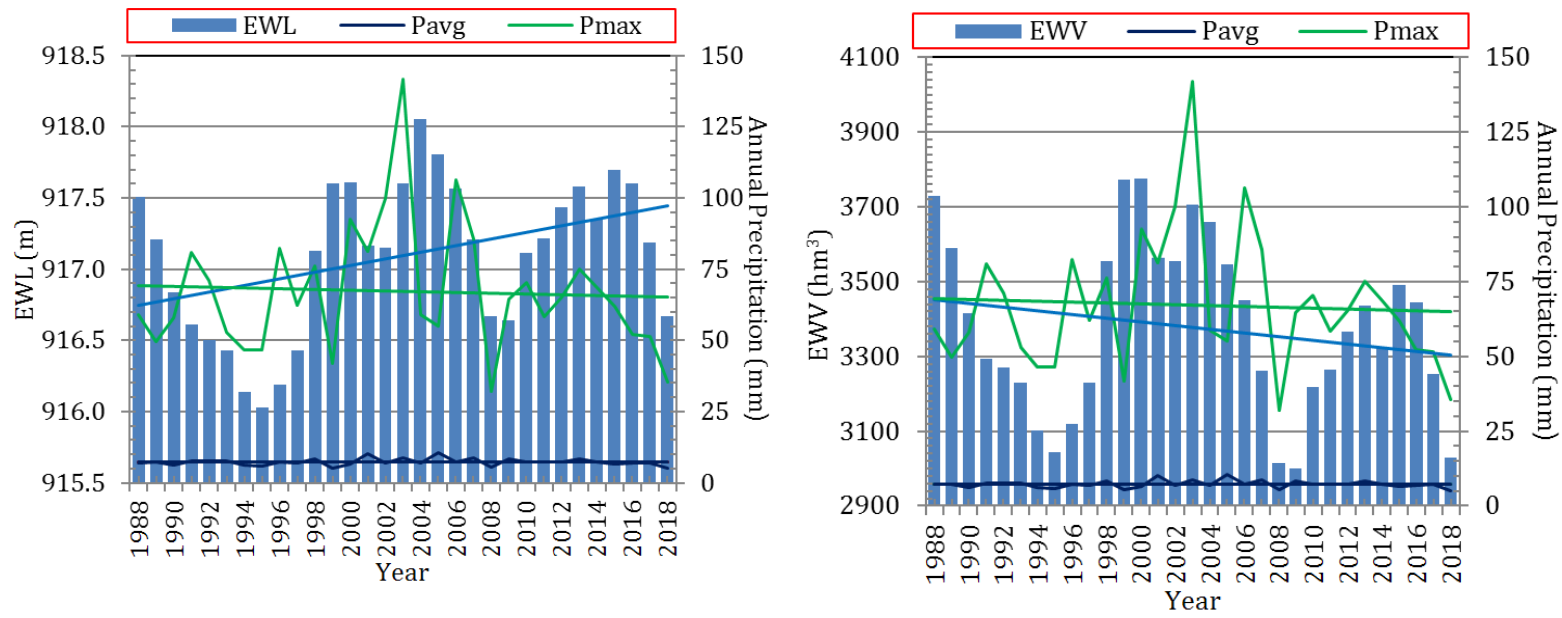

Fig. 2. Changes between EWL and EWV along with temperature values

$T_{\max }$ values increase due to the local impact of climate change, which leads to the increase in evaporation at the lake. Increase in evaporation will lead to a decrease in the values of EWL and EWV.Also Tayebeh et al. [30] reported significant lake level decrease due to the rainfall reduction and increase in evaporation and temperature. Similarly, Figure 3 presents the changes between EWL and EWValong with precipitation values.

Based on the Egirdir meteorology station long term rainfall values, it has been observed that the maximum value of $P_{\mathrm{t}}$ was $1106.6 \mathrm{~mm}$ (2009), while the minimum value was $455.7 \mathrm{~mm}$ (2008) with an average value of $773.39 \mathrm{~mm}$. Whereas the maximum value of $P_{\max }$ was $141.9 \mathrm{~mm}$ (2003), the minimum value was $32 \mathrm{~mm}$ (2008), while the maximum value for $P_{\text {avg }}$ was $10.408 \mathrm{~mm}$ (2005), the minimum value was $5.022 \mathrm{~mm}$ (2018) with an average value of $7.280 \mathrm{~mm}$. It was noticed, when the changes in theEgirdir meteorology station $P_{\mathrm{t}}, P_{\text {avg }}$ and $P_{\max }$ values were observed, that $P_{\mathrm{t}}$ has decreased by $140.9 \mathrm{~mm}(15.51 \%), P_{\text {avg }}$ by $2.066 \mathrm{~mm}(29.14 \%)$ and $P_{\max }$ by $23.80 \mathrm{~mm}(40.20 \%)$ (Figure 3). It was also noticed that the EWL and EWV values have a decreasing trend since 2004 and that the $P_{\mathrm{t}}$ values have also decreased accordingly.

It can be indicated that the EWL and EWV values have been affected by the imbalances and lower amount of rainfall, as well as the increase in temperature at the Egirdir region. The increase in 
temperature led to an increase in evaporation from water surfaces leading to adverse impacts on the values of EWL and EWV. In addition, the increase in drinking water consumption related with Lake Egirdir along with water consumption due to various agricultural activities should not be ignored.
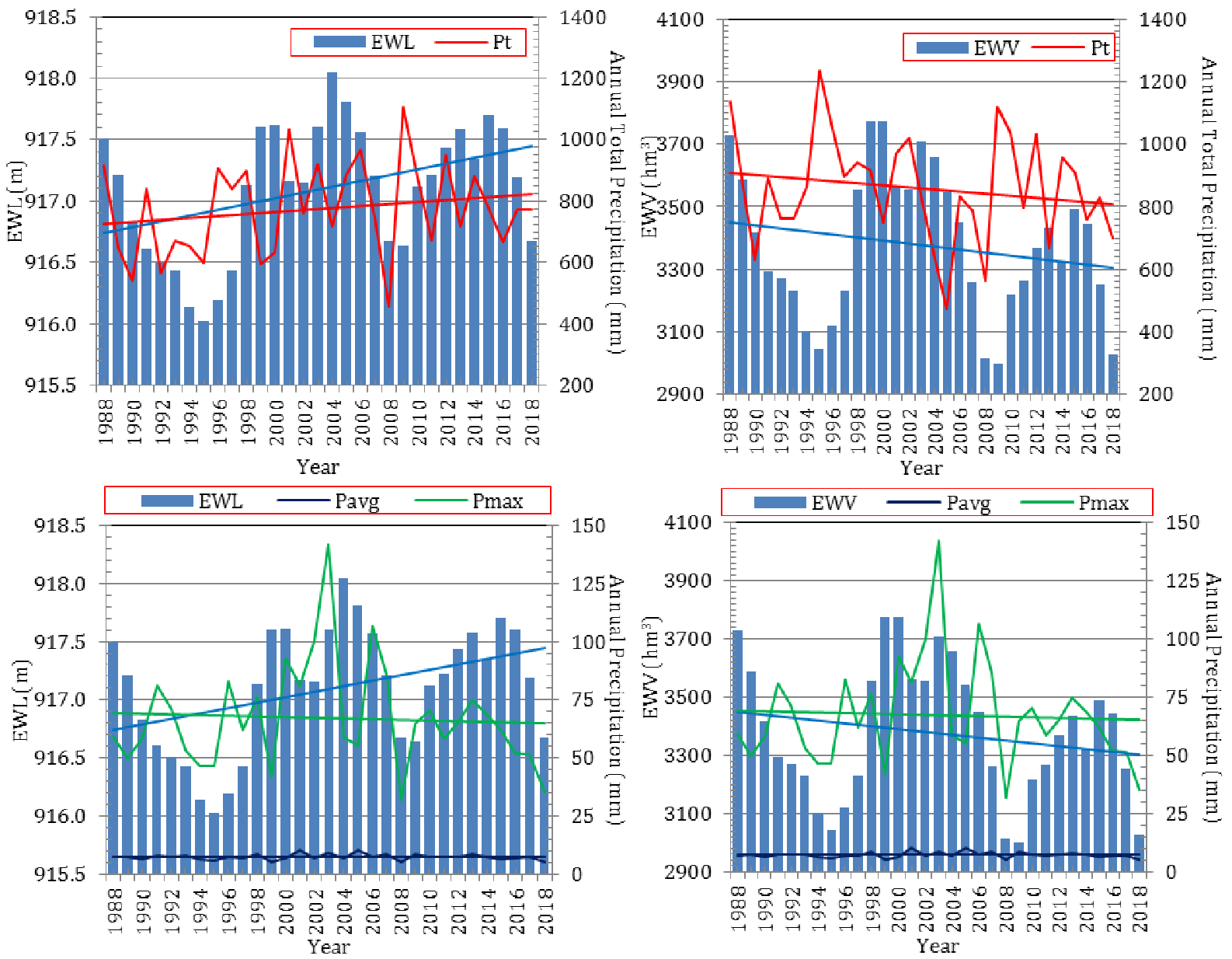

Fig. 3. Display of changes between EWL and EWV along with precipitation values

Yüksel et al. [7] reported that the temperatures continue to increase and that they will increase further by $2{ }^{\circ} \mathrm{C}$ at the end of the century leading to increase in water surface evaporation and decrease in underground water levels. Whereas Gökkur [9] emphasizes that the changes in the temperature regime affect the time-amount of rainfall and snowfall thereby changing the underground and surface water amounts. The increase in temperature speeds up evaporation, which results in the decrease in the irrigation water volume. Therefore, our findings are in accordance with those of Yüksel et al. [7] and Gökkur [9]. It has been concluded that the decrease in the values of EGH and EWL is due to the increase in the temperature values around the lake basin along with the decrease in the rainfall regime. Also, Bartoali et al. [31] reported that in recent years fluctuations of the basin water levels are influenced by changes in precipitation, evaporation, and evapo-transpiration. The indications of the changes between the Egirdir lake EWL and EWV and the relative humidity values are given in Figure 4. It was noticed, when the Egirdir long term relative humidity values were observed, that; the maximum value for $R H_{\max }$ was $99.8 \%$, while the minimum value was $90.70 \%$, the maximum value for $R H_{\text {avg }}$ was $72.69 \%$, while the minimum value was $60.15 \%$ and that the average value was $66.93 \%$, the maximum value for $\mathrm{RH}_{\min }$ was $43.70 \%$, while the minimum value was $19.00 \%$. It was noticed, when the relationships between EWL and EWV and relative humidity were observed, that when EWL and EWV have decreased during the 2004-2018 period, the $R H_{\max }$ values have increased. Similarly, it was noticed that the EWL and EWV values were in parallel during the indicated dates with the values of $R H_{\text {avg }}$ and $R H_{\text {min. }}$. It can be stated that changes have been observed in relative humidity values subject to changes in local climate, especially, starting from 2004.

Also, it was noticed, when the Egirdir long term wind speed values were observed, that (Figure 5): the maximum value for $V_{\max }$ was $12.60 \mathrm{~m} \cdot \mathrm{sec}^{-1}$, while the minimum value was 
$7.70 \mathrm{~m} \cdot \mathrm{sec}^{-1}$, the maximum value for $V_{\text {avg }}$ was $3.578 \mathrm{~m} \cdot \mathrm{sec}^{-1}$, while the minimum value was 2.771 $\mathrm{m} \cdot \mathrm{sec}^{-1}$ and that the average value was $3.095 \mathrm{~m} \cdot \mathrm{sec}^{-1}$, the maximum value for $V_{\min }$ was $1.10 \mathrm{~m} \cdot \mathrm{sec}^{-1}$, while the minimum value was $0.00 \mathrm{~m} \cdot \mathrm{sec}^{-1}$.It was concluded that; $V_{\max }$ decreased by $2.0 \mathrm{~m} \cdot \mathrm{sec}^{-1}$ $(19.417 \%), V_{\text {avg }}$ decreased by $0.783 \mathrm{~m} \cdot \mathrm{sec}^{-1}(19.417 \%)$ and $V_{\min }$ decreased by $0.10 \mathrm{~m} \cdot \mathrm{sec}^{-1}(10.0 \%)$. While there was a decrease of $1.379 \mathrm{~m}(0,150 \%)$, especially in EGS values as of 2004, it was observed that there was a decrease of about $2.0 \mathrm{~m} \cdot \mathrm{sec}^{-1}(19.417 \%)$ in $V_{\max }$ after 1988, a decrease of $0,783(22.033 \%)$ in $V_{\text {avg }}$ values as of 1988 and an increase of $0.10 \mathrm{~m} \cdot \mathrm{sec}^{-1}(10.00 \%)$ in $V_{\min }$ as of 1988 .
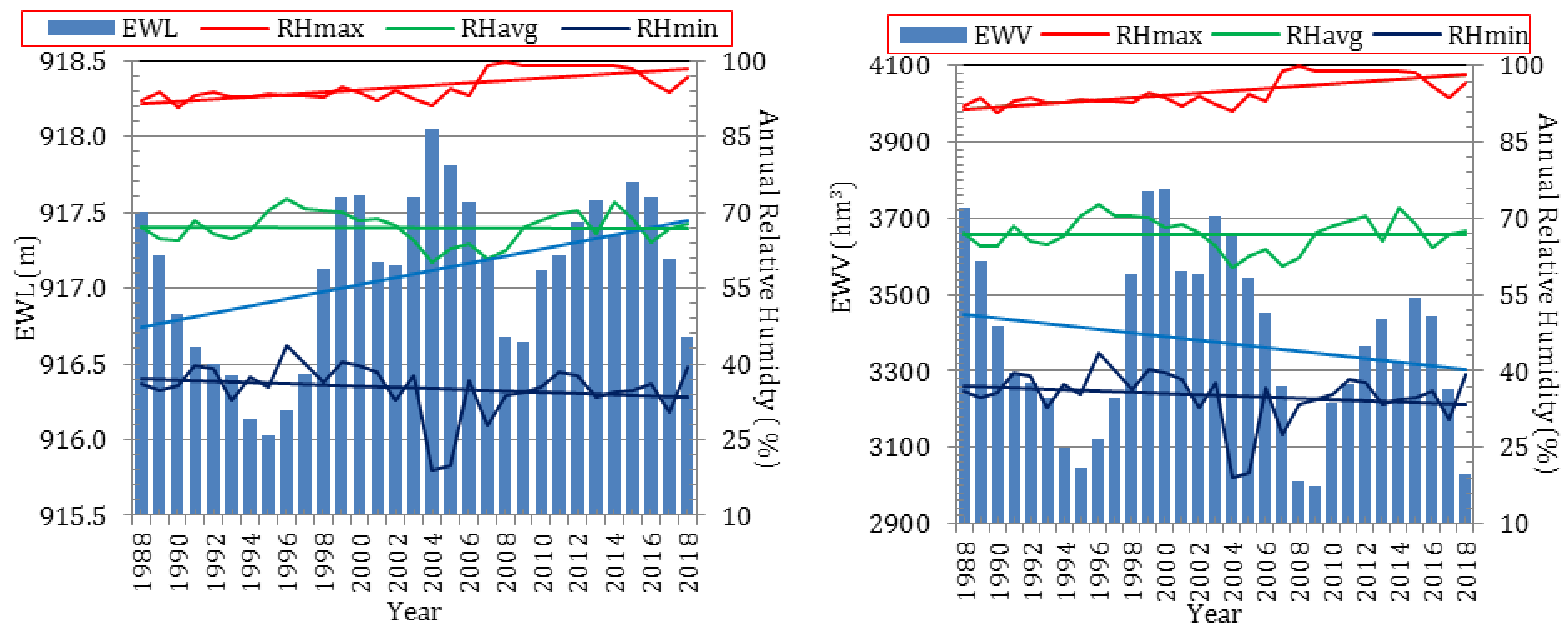

Fig. 4. Display of changes between EWL and EWV along with relative humidity values
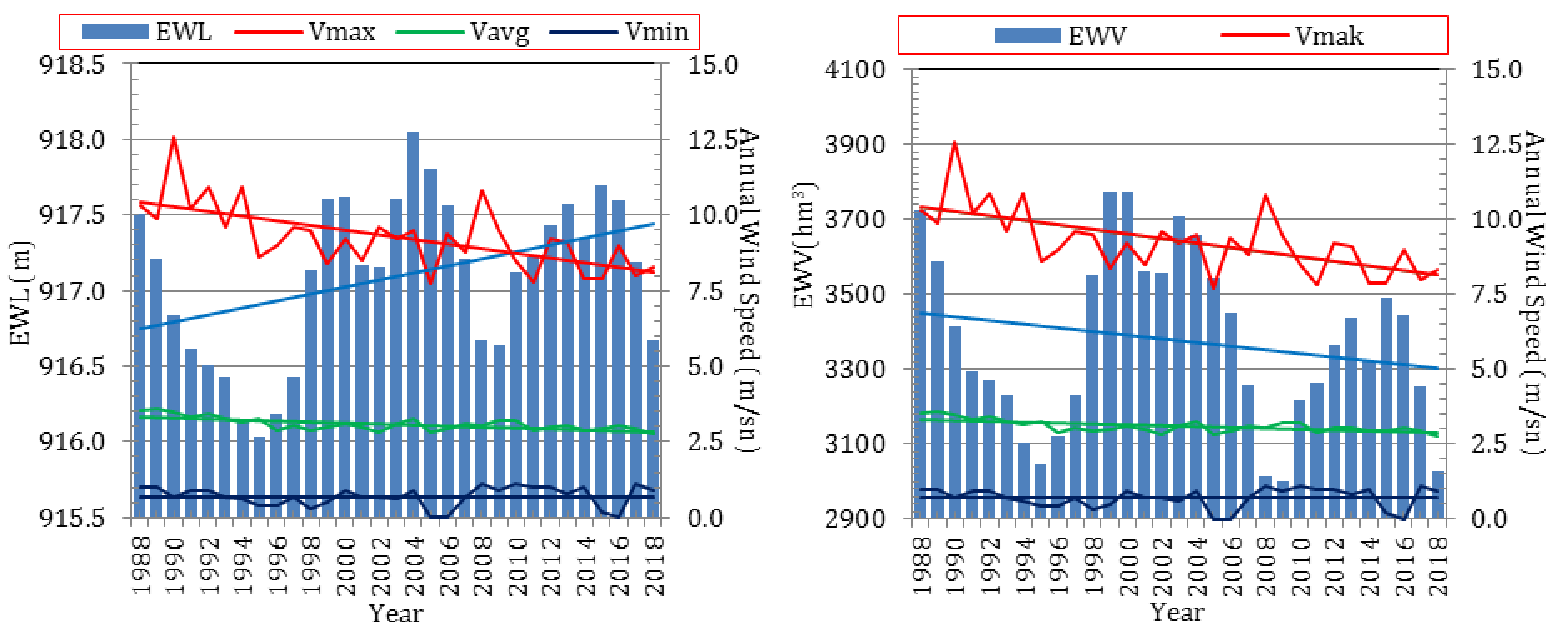

Fig. 5. Display of changes between EWL and EWV along with wind speed values

Correlation analyses. Separate correlation (r) analyses were carried out for determining the statistical significance and direction between the EWL and EWV values (dependent variable) and temperature, precipitation, relative humidity and wind speed (independent variables) in addition to determining the independent variable(s) that have the greatest impact on the EWL or EWV values. As a result of the correlation analyses carried out separately for both dependent and independent variables, it was noticed that there were moderate correlations between the EWL values and $R H_{\text {min }}$ $(-0.433)$ and $V_{\max }(-0.362)$, between the EWV values and $P_{\max }(0.385)$ and $R H_{\max }(-0.384)$. The impacts of other independent variables on the EWL and EWV values were observed to be statistically insignificant based on the $\mathrm{r}$ and $p(<0.05)$ values. Also, it was noticed that there is an inverse proportion between the EWL values and $R H_{\min }, V_{\max }$ values, a linear proportion between the EWV values and $P_{\max }$ and an inverse proportion with the $R H_{\max }$ values.

\section{Conclusions}

It is considered that climate changes have taken place at Lake Egirdirselected as the study area. These changes were noticed especially as increases in temperature and decreases in precipitation. It 
was concluded that increase in temperature values will lead to an increase in evaporation, whereas decrease in precipitation will have an adverse impact on the amount and volume of water masses. It is clear that the EWL and EWV values have decreased continuously, starting especially from 2004. In this regard, it is concluded that the decrease in the values of EWL and EWV are due to the changes in temperature and precipitation. Even though the relationship between the changes in temperature, precipitation and the values of EWL and EWVwere statistically significant at a moderate level, it can be stated that is very significant for practice. Therefore, it is concluded that the future plans for water use of Lake Egirdir should be sincerely revised, since it is the second largest fresh water lake of Turkey.

\section{References}

[1] Göller ve Sulak Alanlar Eylem Planı 2017-2023 (Lakes and Wetlands Action Plan 2017-2023), Republic of Turkey, Ministry of Agriculture and Forestry, General Directorate of Water Management, 2017, 194 p., Ankara.(In Turkish).

[2] Erol O. Genel Klimatoloji (General Climatology), Gazi Office Bookstore, 1993, Ankara. (In Turkish).

[3] Davraz A., Şener Ş., Şener E.Su Kaynaklarının Kullanma ve Koruma Metodolojinin Geliştirilmesi: Eğirdir Gölü Havzası Örneği (Improving of Usage and Protection Methodology of Water Resources: A Case Study of Egirdir Lake Basin)Journal of Engineering Sciences and Design 4(3), 2016 pp. 227-238.(In Turkish).

[4] Sarp S., Buldur A. D. Topoğrafyanın Minimum Ekstrem Sicaklıklara Etkisi (Karaman-Hadim Örneği) (The Effect of Topography on Minimum Extreme Temperatures (Karaman-Hadim Example), Turkish Studies International Periodical for the Languages, Literature and History of Turkish or Turkic, 12(29), 2017 pp. 487-504. (In Turkish).

[5] Büyükyıldız M., Yılmaz V. Türkiye'deki Bazı Göllerin Su Seviyesindeki Değişimlerin İncelenmesi (Investigation of Water Level Changes of Some Lakes in Turkey) e-Journal of New World Sciences Academy, 6(4) 2011, pp. 1061-1073. (In Turkish).

[6] Sandalcı M., Yüksel İ. İklim Değişikliğinin Türkiye'deki Göller ve Barajlar Üzerindeki Etkisi (Lakes and Dams Impact on Climate Change in Turkey), Yapı Dünyası Dergisi, 181, 2011 pp. 2529. (In Turkish).

[7] Yüksel İ., Sandalcı M., Çeribaşı G., Yüksek Ö. Küresel Isınma ve İklim Değişikliğinin Su Kaynaklarına Etkileri (Effect of the global warming and climate change on water resources), National 7th Coastal Engineering Symposium, 2011, pp.51-58, Trabzon. (In Turkish).

[8] Aydın F. A., Doğu A. F. Göllerde Seviye Değişimleri ve Nedenleri: Van Gölü Örneği, (Level Changes and Reasons in Lakes: The Example of Lake Van), The Journal of Social Sciences Institute, 2018-Autumn, 41, 2018 pp.183-208. (In Turkish).

[9] Gökkür S. İklim Değişikliğinin Su Kaynaklarına Etkisi (Impact of climate change on water resources), Journal of Apelasyon, September-2016, Number 34.(In Turkish).

[10] Bayraktar S. Göllerin ve Haznelerin Hidrolojik Değerlendirilmesi (Hydrological Evaluation of Lakes and Reservoirs), Sakarya University, Institute of Natural and Applied Sciences, 2004,Master Thesis. (In Turkish).

[11]Tan C., Ma M., Kuang H. 2017. Spatial-Temporal Characteristics and Climatic Responses of Water Level Fluctuations of Global Major Lakes from 2002 to 2010.Remote Sensing, 9(2) 150.; doi:10.3390/rs9020150

[12] Vuglinskiy V., 2009. Water Level Version B, Water Level in LakesandReservoirs, Water Storage, Global TerrestrialObservingSystem, GTOS: 59,Assessment of TheStatus of The Development of TheStandardsForTheTerrestrialEssentialClimateVariables, T4, 17 p., Rome.

[13] Wu Y., 2019. Integration of Earth Observationand in Situ Data ForAnalyzing Lake Level Changes in Minnesota (1992-2016), Master of Arts in Geography in the Graduate School of Binghamton University State University of New York, Xi'an University of Science and Technology, MSc Thesis, $49 \mathrm{p}$.

[14]Hoşgören M.Y. Türkiye'nin Gölleri (Lakes of Turkey), Turkish Geographical Review 29, 1994 pp.19-51.(In Turkish).

[15] Kesici E., Kesici C. Eğirdir Gölü (Isparta)'nün Doğal Yapısına Yapılan Müdahalelerin Gölün Ekolojik Yapısına Etkileri (Effects of Interventions on the Natural Structure of Eğirdir Lake 
(Isparta) on the Ecological Structure of the Lake), Ege Journal of Fisheries and Aquatic Sciences, 23 (Suplemental no 1/1) 2006, pp. 99-103. (In Turkish).

[16] Anonymous. Isparta İli 2017 Yılı Çevre Durum Raporu (Environmental Status Report for Isparta Province in 2017.), T. C. Çevre ve Şehircilik Bakanlığı, Isparta Valiliği, Çevre ve Şehircilik İl Müdürlüğü, 74 sayfa, 2018 Isparta. (In Turkish).

[17] Kargı H. Gözbebeğimiz Eğirdir Gölü Paneli: Sorunlar \& Çözümler (Our eyeball Egirdir Lake Panel: Problems and Solutions) ISBN: 978-605-9454-37-7, 2019, pp. 51-55. (In Turkish).

[18] Davraz A., Şener E., Şener Ş., Varol S. Water Balance of the Eğirdir Lake and the Influence of Budget Components, Isparta,Turkey, Suleyman Demirel University Journal of Natural and Applied Science, 18(2)2014pp.27-36.

[19] Anonymous, 2019a. Eğirdir Gölü Su Seviyesi Verileri (Egirdir Lake Water Level Data), State Hydraulic Works 18. District Office, Isparta. (In Turkish).

[20] Anonymous, 2019b. Eğirdir Meteorolojik Verileri (Egirdir Meteorological Data), Republic of Turkey, General Directorate of Meteorology, Ankara. (In Turkish).

[21] Orhunbilge N., 1996. Uygulamalı Regresyon ve Korelasyon Analizi (Applied Regression and Correlation Analysis), IÜ. Faculty of Business, No:267, İstanbul.(In Turkish).

[22] Kadılar C. SPSS Uygulamalı Zaman Serileri Analizine Giriş (Introduction to SPSS Applied Time Series Analysis), Bizim of Printing Office, 2005, Ankara.(In Turkish).

[23] Xu C. Statistical Methods in Hydrology (Lecture notes), Uppsala University Department of Earth Sciences Air, Water, and Landscape Science, 2009, 129 pp. Uppsala, Sweden.

[24] Starnes D. S., Tabor J., Yates D.S., Moore D.S. The Practice of Statistics For the AP® Exam, Fifth Edition, 2014 pp. 978 W. H. Freeman and Company/BFW, New York.

[25] Maity R. Statistical Methods in Hydrology and Hydroclimatology, Springer Transactions in Civil and Environmental Engineering Book series. Civil Engineering,2018pp. 366 Singapore.

[26] Dawson B., Trapp R.G. Basic \& Clinical Biostatistics (LANGE Basic Science), 2004.McGrawHill Medical.

[27] Kılıç S., 2014. Etki Büyüklüğü, Journal of MoodDisorders, StatisticallySpeaking, 4(1): pp. 44-46.

[28] Kul S., 2014. İstatistik Sonuçlarının Yorumu: p Değeri ve Güven Aralığı Nedir?, Türk Toraks Derneği,Ekstraplevral, pp. 11-13.

[29] Motiee H., McBean E. 2009. An Assessment of Long-Term Trends in Hydrologic Components and Implications for Water Levels in Lake Superior. HydrologyResearch, 40:, pp. 564-579.

[30] Tayebeh K., Ramesht M.R., Maleki A., Safakish F.,2017. AnalyzingtheImpacts of Climate Change on Water Level Fluctuations of Tashk and Bakhtegan Lakes and Its Role in Environmental Sustainability. Open Journal of Ecology, (7): pp. 158-178.

[31] Bartolai A.M., He L., Hurst A.E., Mortsch L., Paehlke R. Scavia, D. (2015) Climate Change as a Driver of Change in the Great Lakes St. Lawrence River Basin. Journal of Great Lakes Research, 41, pp. 45-58. 